\title{
HUKUM PERJUD IAN PADA SAAT UPACARA ADAT DI DESA PENINJOAN TEMBUKU BANGLI
}

\author{
Oleh: \\ Dewa Nyoman Tria Harry Shureshta ${ }^{1}$, I Made Suwitra ${ }^{2}$, I Nyoman Subamia ${ }^{3}$ \\ ukiitria@gmail.com ${ }^{1}$, madesuwitra27@gmail.com², doktorsubamia@gmail.com ${ }^{3}$
}

Universitas Warmadewa, Denpasar, Bali

\begin{abstract}
Abstrak
Tujuan dari penelitian ini adalah untuk melaksanakan Tri Dharma Perguruan Tinggi khususnya dalam bidang penelitian serta untuk memperoleh gelar Sarjana dalam bidang ilmu hukum. Rumusan masalah dalam penelitian ini, yaitu bagaimanakah eksistensi perjudian saat upacara adat di Desa Peninjoan, Tembuku, Bangli? dan bagaimanakah penanggulangan perjudian di Desa Adat Peninjoan, Tembuku, Bangli? Tipe penelitian yang digunakan adalah tipe penelitian hukum empiris. Metode pendekatan yang digunakan adalah pendekatan terhadap masyarakat. Sedangkan teknik pengumpulan bahan hukum yang digunakan adalah observasi. Adapun kesimpulan dari penelitian ini adalah sering terjadinya perjudian pada saat upacara adat yang dilakukan oleh beberapa warga di Desa Peninjoan, Tembuku, Bangli yang dilakukan terangterangan, maupun sembunyi-sembunyi. Namun itu dilakukan pada saat hari raya besar agama Hindu. Adapun upaya penanggulangan tindak pidana perjudian oleh kepala desa peninjoan, Ada dua teoripenanggulangan yang telah dilakukan termasuk kejahatan perjudian ini khususnya, yaitu pola Preventif (dilakukan pencegahan sebelum terjadinya kejahatan) dan pola Represif (pencegahan setelah terjadinya kejahatan, kejahatan ini biasanya disebut proses secara hukum).
\end{abstract}

\section{Kata kunci Tindak Pidana, Perjudian Pada Saat Upacara Adat, Penanggulangan}

\section{PENDAHULUAN}

Suatu Negara pasti mengimplementasikan hukum guna dapat mengatur rakyatnya. Negara Indonesia merupakan salah satu Negara hukum. Tentunya dalam ha! ini tidak dapat dianulir lagi dikarenakan tercantum didalam Undang-Undang Dasar NRI 1945. Hukum tidak dapat dipisahkan dari kehidupan berbangsa dan bemegara. Eksistensi hukum sangat berperan penting untuk suatu negara. Karenanya hukum dipandang sebagai dasar bersifat utama, lebih-lebihnya untuk mengatur jalannya suatu pemerintahan.

Melalui hukum juga akan terciptanya keadilan serta ketertiban masyarakat. Maka oleh sebab itulah meminimalisir adanya kesenjangan dalam masyarakat. Melalui eksistensi hukum, tingkat kriminalitas akan diminimalisir. 
Pemegang kekuasaan tidak dapat bersikap kesewenang-wenangan dikarenakan dibatasi dengan adanya hukum. Sisi lain hukum justru membantu dalam melindungi hak serta kewajiban setiap warga Negara. Maka suatu Negara harus merniliki sistem hukum yang tepat.

Semakin seseorang tersebut taat hukum, dengan demikian dapat disimpulkan kalau tingkat kesadaran hukum juga tinggi. Melanggar hukum adalah Tindakan seseorang atau sekelompok yang melanggar aturan dan tidak sesuai dengan hukum • hukum yang berlaku. Pelanggaran hukum merupakan bentuk sikap penentangan terhadap aturanaturan hukum yang berlaku, salah satunya adalah tindakan perjudian. Pelanggaran hukum itu bisa terjadi karena dua hal, yaitu pelanggaran yang oleh si pelanggar sudah dianggap sebagai bentuk kebiasaan serta kebutuhan. Hukum diciptakan dengan tujuan mengatur kehidupan masyarakat, bukan dilanggar atau ditentang oleh masyarakat.

Berjudi secara universal dianggap sebagai bentuk penyakit masyarakat. Tindakan bermain judi atau turut serta bermain judi telah dilarang dan diatur ketentuan hukum pidana Pasal 542 KUHP, kemudian aturan serta ketentuan tersebut diatur juga dalam Pasal 2 ayat (4) UU No. 7 tahun 1974 tentang penertiban perjudian, selanjutnya telah diperbaharui sebutannya menjadi ketentuan pidana yang diatur dalam Pasal 303 bis KUHP.

Berjudi adalah sebuah permainan yang meliputi segala perjanjian, pertaruhan mengenai keputusan perlombaan atau permainan lainnya yang tidak diselenggarakan oleh mereka yang ikut berlomba atau bermain itu, demikian juga termasuk segala jenis pertaruhan lainnya. Sudut pandang kriminologi, memandang delik perjudian masuk kategorikan sebagai tindakan kejahatan tidak dengan korban (crime without victim), hal ini dikarenakan aktivitas perjudian tersebut ialah pelaku itu sendiri. Namun, jikalau dikaji lebih jauh, tindakan permainan judi juga melibatkan orang lain. Tindakan berjudi akan memberikan pengaruh dalam keadaan sosial maupun perekonomian, justru memicu terciptanya tindakan kriminal yang lain.

Adapun segelintir masalah yang ditimbulkan atas akibat perjudian diantaranya bahwa orang yang bermain judi akan menjadi ketagihan, mereka tidak mampu berhenti berjudi, dan pada akhimya akan kehilangan banyak harta. Dengan demikian sudah jelas bahwa berjudi itu merugikan diri sendiri, merugikan masyarakat karena selain mempengaruhi jiwa seseorang, juga dapat melemahkan perekonomian masyarakat secara luas. Pada sisi lain berakibat merugikan, kondisi psikis maupun kesehatan, serta mempengaruhi para penjudi menjadi pemalas, yang akhirnya justru akan mempermudah untuk melakukan tindakan kriminal diantaranya mencuri, tindakan korupsi, dan bahkan pembunuhan.

Upaya tindakan terhadap bentuk perbuatan ini dialami oleh masyarakat, kejahatan tersebut meliputi perjudian, delik 
pencurian kekerasan/pemberatan, penganiayaan sampai dengan pembunuhan, serta perilaku menyimpang termasuk kejahatan lainnya, diharapkan penegakan yang masif dan intensif, utamanya yang terjadi di tempat-tempat objek rawan, yang memicu serta mengakibatkan instabilitas tentunya perekonomian. Kemudian bermacam kriminalitas yang kerap terjadi itu, niscaya diklasifikasikan dan diprioritaskan dengan akselerasi utama yaitu perjudian.

Menurut Robert Carson dan James Butcher (1992) dalam buku Abnormal Psychology and Modern Life, mengartikan berjudi termasuk dalam kelakuan memasang taruhan dalam suatu permainan maupun kejadian dengan keinginan untuk mendapatkan untung serta keberhasilan. Dasar pokok dalam berjudi umumnya yakni untuk memperoleh untung jikalau berhasil. Nominal besar jumlah yang dipertaruhkan angkanya, begitu juga besar hasil kemenangan yang didapat. Judi kartu ceki a tau domino, tajen, bola-bola merupakan judi yang ban yak dijumpai di daerah Bali, apalagi saat adanya upacara adat. Bali merupakan salah satu objek wisata di Indonesia yang memiliki banyak tradisi dan budaya tentunya dengan nuansa Hindu Bali.

Perspektif mitologi serta legenda, cara untuk mengetahui sejarah dalam masyarakat diantaranya kurang memahami tulisan sehingga memilih upacara. Makna yang dimaksud bukan dalam pengertian upacara secara formal, layaknya upacara penghormatan bendera. Menggelar upacara mempunyai nilai sakralitas dalam masyarakat sebagai penunjang kebudayaan tersebut. Dikarenakan ha! itu merupakan rangkaian aktivitas yang ditekankan mengenai batasan tertentu atas eksistensi adat, agama, maupun kepercayaan.

Terdapat beberapa bentuk peristiwa penting yang dijumpai dalam kehidupan masyarakat berupa penguburan jenazah, perkawinan, serta peristiwa pengukuhan kepala suku. Peristiwa pen ting kebiasaan adat yaitu suatu yang dilaksanakan dengan turuntemurun dan berlaku untuk suatu daerah. Maka, setiap daerah berbeda mempunyai kebiasaan adat yang tidak sama, selayaknya perkawinan, labuhan, cemas pusaka, dan lainnya. Dilaksanakannya suatu bentuk perayaan peristiwa penting sebenarnya tidak jauh daripada nilai sejarah. Agama Hindu di pulau Bali mempunyai bentuk-bentuk upacara keagamaan memiliki relevansi terhadap bentuk pemujaan maupun ritual yang ditujukan kepada dewa (Tuhan), rsi, pitra (leluhur), manusia dan bhuta (mahluk darialam lain) semua itu dikenal dengan Panca Yadnya. Namun, saat peristiwa perayaan adat berlangsung, banyak orang justru melakukan kegiatan perjudian.

Berdasarkan uraian permasalahan yang telah penulis kemukakan diatas, maka dapat ditarik rumusan-rumusan permasalahan pokok diantaranya yaitu:

1. Bagaimanakah eksistensi perjudian saat upacara adat di Desa Peninjoan, Tembuku, Bangli? 


\section{Bagairnanakah}

penanggulangan perjudian di

Desa Adat Peninjoan, Tembuku, Bangli?

Sehingga, tujuan daripada penelitian ini antara lain:

1. Untuk mengetahui eksistensi perjudian saat upacara adat di Desa Peninjoan, Tembuku, Bangli.

2. Untuk mengetahui penanggulangan perjudian di Desa Adat Peninjoan, Tembuku, Bangli.

\section{Metode Penelitian}

Tipe penelitian yang digunakan adalah tipe penelitian hukum empiris. Tipe penelitian ini merupakan metode yang memuatkan fakta yang didapat melalui perilaku manusia, meliputi perilaku verbal berdasar atas wawancara ataupun perilaku nyata yang diupayakan melalui observasi lapangan. Tipe penelitian ini digunakan untuk memantau hasil dari tingkah laku manusia, berupa peninggalan fisik ataupun arsip (Mukti Fajar dan Yulianto Achmad, 2010 280).

Mengenai sumber data yang digunakan terbagi atas sumber data primer, yaitu data yang didapat langsung dari masyarakat sebagai sumber pertama melalui penelitian lapangan (pengamatan, wawancara, dan kuisioner). Dan sumber data sekunder, yaitu data yang diperoleh melalui studi kepustakaan. Untuk memperoleh data ini peneliti mengambil sejumlah buku-buku, brosur, website, dan contoh penelitian sebelumnya yang berkaitan dengan penelitian ini (Burhan Bungin, 2005 119).

Pengumpulan data dilakukan melalui wawancara, yaitu teknik pengumpulan data yang dilakukan dengan cara tanya jawab yang berlangsung satu arah untuk tujuan tertentu. Dan dokumentasi yaitu, mencari data mengenai variabel berupa catatan, buku, surat kabar dan lain-lain.

Setelah data-data yang dibutuhkan terkumpul, maka data tersebut selanjutnya diolah dan dianalisis dengan menggunakan teknik pengolahan data secara kualitatif. Pengolahan data secara kualitatif dimaksud mengolah data sesuai dengan fakta yang terjadi di lapangan secara bermutu dalam bentuk kalimat yang teratur, logis, runtut dan tidak saling tumpang tindih yang nantinya akan mempermudah pemahaman dan interpretasi data.

Lokasi penelitian ini di desa Peninjoan, Tembuku, Bangli, karena disana masih banyak warga lokal yang melakukan perjudian pada saat melakukan upacara adat.

\section{PEMBAHASAN}

\subsection{Eksistensi Perjudian Di Desa} Peninjoan, Tembuku, Bangli

Perjudian merupakan pertaruhan yang sengaja dengan mempertaruhkan satu benda maupun sesuatu yang bernilai, dengan menyadari terdapatnya resiko serta harapan tertentu pada 
peristiwa permainan, perlombaan dan kejadian yang tidak ataupun hasilnya belum ten tu (Kartini Kartono, 1981 51). Pendapat G.W. Bawengan memuatkan bahwa permainan judi yaitu mempertaruhkan benda berharga, dengan harapan memperoleh untung atas spekulasi semata (G.W. Bawengan,

Mengharapkan keuntungan maupun harapan kemenangan adalah hal yang merupakan daya tarik tersendiri dalam perjudian. Perjudian sebetulnya sudah ada pada zaman dahulu oleh masyarakat.

Awalnya definisi perjudian itu diketahui masyarakat yaitu permainan, melalui bentuknya maupun jenisnya yang disertakan taruhan, tindakan itu identik dikenal dengan totohan dalam bahasa jawa. Sebutan itu diberikan masyarakat kerap kali mengaburkan definisi perjudian, segelintir orang menganggap perjudian merupakan sesuatu yang identik dengan taruhan. Mereka tahu kalau telah melakukan perjudian, namun nyatanya hal itu dilakukan karena untuk mengisi waktu kosong. Banyak masyarakat memberikan tanggapan mengenai perjudian, perberbedaan tanggapan mereka yang kontra perjudian menganggap sebagai suatu aktivitas yang berdosa, serta haram hukumnya. Tetapi yang menerima perjudian, justru mendorong perjudian dijadikan sumber perekonornian konvensional, selain itu ada masyarakat yang bersifat netral.

Dalam upacara adat di Bali kadang juga terdapat jenis-jenis perjudian, yaitu:

1) Adu ayam

2) Ceki

3) Kartu domino (spirit)

4) Bola adil

5) Kocok dadu

Dalam penjelasan di atas, dikatakan bahwa bentuk perjudian seperti adu ayam, karapan sapi dan sebagainya itu tidak termasuk perjudian apabila kebiasaankebiasaan yang bersangkutan berkaitan dengan upacara keagamaan dan sepanjang kebiasaan itu tidak merupakan perjudian. Tetabuhan dengan sarana binatang, khususnya ayam, dalam pelaksanaannya cukup unik, karena pelaksanaannya hampir selalu dilakukan dengan menyabung dua ekor ayam jantan, sampai salah satu meneteskan darah, dan bahkan sampai salah satunya mati. Di dalam pelaksanaan tabuh rah juga mengenal adanya taruhan yang lebih dikenal dengan Toh Dedamping (Ida Bagus Putu Purwita, I 989 I). 
https://ejournal.warmadewa.ac.id/index.php/wicaksana

Selama saya melakukan penelitian

di

Desa

Peninjoan,Tembuku, Bangli, saya mendapatkan penjelasan dari Dewa Gede Ary Astika selaku ketua mudamudi di desa Peninjoan bahwa disana sudah sering terjadi perjudian pada saat upacara adat, baik itu sembunyi-sembunyi maupun terang-terangan.

Perjudian yang sering terjadi di Desa Peninjoan pada saat upacara adat tersebut adalah

1) Adu ayam

2) Kartu ceki

3) Domino/spirit/brerong

4) Bola adil

5) Dadu/Kocok mong

6) Adu Jangkrik

Menurut beberapa warga setempat disana yang saya tanyakan di desa tersebut sering terjadi perjudian pada saat upacara adat karena adanya beberapa faktor, yaitu:

1) Semata-mata hanya untuk sebuah hiburan

2) Suatu kebiasaan warga di desa tersebut

3) Ingin menggandakan uang yang telah dimiliki

Namun mereka melakukan perjudian tersebut hanya pada saat upacara adat/hari raya besar agama Hindu, akan tetapi yang saya ketahui perjudian tersebut melanggar KUHP karena menggunakan uang sebagai taruhan, sedangkan warga setempat menganggap perjudian tersebut adalah suatu kebiasaan yang sering terjadi pada saat upacara adat di desa tersebut agar dapat meramaikan upacara adat yang sedang berlangsung.

Dari informan yang juga selaku kepala Desa di peninjoan sudah menghimbau masyarakatnya agar tidak berjudi lagi, apalagi dilakukan terangterangan. Akan tetapi warga di desa tersebut tetap melakukan kegiatan berjudi tersebut karena menganggapnya menjadi suatu kebiasaan untuk meramaikan upacara tersebut dan panitia penyelenggara tersebut mengungkapkan bahwa hasil judi tersebut nanti akan digunakan sebagai penggalangan dana untuk pura maupun desa adat. Perjudian tersebut sering dilakukan terangterangan. Dan sudah beberapa kali dibubarkan oleh aparat setempat, namun kegiatan perjudian tersebut tetap kembali terjadi.

\subsection{Penanggulangan Perjudian Yang Terjadi Di Desa Peninjoan, Tembuku, Bangli}


Terdapat dua teori proses menanggulangi kejahatan perjudian khususnya yang dapat dilakukan, diantaranya melalui prosedur preventif (melaksanakan pencegahan) dan melalui prosedur represif (penindakan akhir). Pada Wilayah Desa peninjoan, berdasar pada hasil wawancara bersama Bapak I Putu Joantara selaku Kepala Desa tentang upaya pencegahan serta penanggulangan melalui dengan cara preventif atas tindakan perjudian, maka Kepala Desa Peninjoan melaksanakan upaya terdiri atas:

1. Himbauan kepada setiap masyarakat desa untuk tetap dan selalu bersiap siaga atas kemungkinankemungkinan yang terjadi yang ditimbulkan dari adanya gangguan orang yang tidak memiliki rasa tanggung jawab.

2. Menciptakan program pendidikan maupun sosialisasi hukum di setiap organisasi pemuda sejenis karang taruna, sekolahsekolah, dengan mengikutsertakan bagian daripada warga masyarakat, diantaranya tokoh adat serta pemuka agama yang dilaksanakan setiap wilayah bersangkutan.

3. Memberdayakan setiap lembaga dan organisasi sosial, untuk turut serta mengkampanyekan gerakan melawan kejahatan meliputi gerakan lawan narkoba, stop konsumsi rninuman keras serta perjudian di kecamatan maupun kelurahan. Lain daripada itu, penindakan melalui pola represif untuk tindak pidana perjudian guna pencegahan serta menanggulangi delik tersebut berdasar pada hasil wawancara bersama dengan Bapak I Putu Joantara selaku Kepala Desa Peninjoan 


\begin{abstract}
mengungkapkan
bahwa dalam setiap

pencegahan melalui

upaya preventif tentu

juga dibarengi dengan

upaya terakhir yaitu

represif hukum.

Penindakan dengan upaya

represif dilaksanakan guna

mengikhtiarkan supaya jangan

terjadi upaya perjudian diantaranya

meliputi:
\end{abstract}

1) Pelaksanaan razia secara optimal dan kondusif. Tindakan tersebut dilaksanakan terutama pada daerahdaerah yang terindikasi dan dikhawatirkan sebagai daerah yang kemungkinan besar dapat melakukan tindakan perjudian.

2) Berupaya melakukan tindak lanjut dengan cepat setiap diketahui terjadinya tindakan perjudian atas adanya informasi masyarakat maupun laporan, apalagi tindakan langsung ditangani oleh pihak berwajib.

Berdasarkan

hasil

wawancara dengan Bapak I Komang Sineb selaku kelian adat di Desa Peninjoan yang mengungkapkan terdapat beberapa kendala maupun hambatan yang dirasakan dalam upaya menanggulangi perjudian, kendala ataupun hambatan berasal dari masyarakat diantaranya:

1) Jumlah profesi penegak hukum salah satunya pihak kepolisian yang bertugas di Polsek Tembuku terbatas, kemudian mengindikasi suatu hambatan dalam menanggulangi perbuatan terlarang yaitu perjudian.

2) Pendukung lainnya untuk biaya operasional dalam melaksanakan penanganan pidana perjudian sangat minim, jikalau diperbandingkan dengan kemajuan 
zaman,justru

kejahatan

ini

dipandang universal

yang cenderung selalu

berinovasi jumlahnya

maupun

modus

pengoprasian

kejahatan

susah

diprediksi secara awal

dikarenakan mengikuti

kemajuan teknologi

serta informasi.

3) Tindakan perjudian dilaksanakan nomaden atau seringkali tempatnya berpindah dari tempat biasa dilakukannya perjudian.

4) Sebagian warga takut dan enggan diikutsertakan menjadi saksi atas perkara pidana perjudian.

5) Kesadaran masyarakat yang kurang mendukung dan berani melaporkan tindak pidana perjudian yang jelas berdampak negatif terhadap masyarakat serta pelaku perjudian itu sendiri.

6) Tidak jarang terdapat oknum kepolisian terlibat sebagai back-up tindak pidana perjudian.

\section{SIMPULAN DAN SARAN}

4.1. Simpulan

1. Eksistensi perjudian saat upacara adat di Desa Peninjoan, Tembuku, Bangli, peneliti mendapatkan penjelasan dari informan bahwa disana sudah sering terjadi perjudian pada saat upacara adat, baik itu sembunyi• sembunyi maupun terangterangan. Perjudian yang sering terjadi di Desa Peninjoan pada saat upacara adat tersebut adalah tajen, kartu ceki, dornino/spirit/brerong, bola adil, dan dadu/kocok mong, dan adu jangkrik. Namun mereka melakukan perjudian tersebut hanya pada saat upacara adat/hari raya besar agama Hindu, akan tetapi yang peneliti ketahui perjudian tersebut melanggar KUHP karena menggunakan uang sebagai taruhan, sedangkan warga setempat menganggap perjudian tersebut adalah suatu kebiasaan yang sering terjadi 
pada saat upacara adat di desa tersebut agar dapat meramaikan upacara adat yang sedang berlangsung.

2. Penanggulangan Perjudian Yang Terjadi di Desa Peninjoan, Tembuku, Bangli, berdasarkan wawancara dengan Kepala Desa tentang upaya dan penanggulangan perjudian secara Preventif, diupayakan melalui himbauan kepada warga masyarakat di setiap kesempatan untuk tetap bersikap siaga dan berhati-hati atas kemungkinan gangguan oleh orang-orang yang tidak memiliki rasa tanggung jawab. Selanjutnya didukung melalui program sosialisasi hukum kepada setiap organisasi kepemudaan dengan mengikutsertakan setiap unsur warga masyarakat. Di tam bah dengan upaya pemberdayaan lembaga sosiaJ yang ada untuk turut serta menggelorakan kampanye gerakan anti kejahatan meliputi gerakan anti narkoba, anti minuman keras serta perjudian di setiap kecamatan serta kelurahan. Begitu juga halnya tindakan pola represif dilaksanakan menunjang tindakan preventif.
Berdasarkan simpulan tersebut diatas, dapat dikemukakan saran kepada para pihak terkait, sebagai berikut:

1. Kiranya perlu ditingkatkan pemahaman masyarakat bahwa judi merupakan salah satu bentuk tindak pidana yang dilarang baik oleh hukum positifkita, maupun oleh norma agama dan kesusilaan. Itu wajib dilakukan pada saat rapat/sangkep, agar dapat memberi pengetahuan terhadap masyarakat yang kurang paham tentang hukum. Dan diberikan sanksi yang tegas kepada mereka yang terbukti secara sah dan meyakinkan melakukan tindak pidana perjudian. Dengan adanya sanksi pidana tersebut diharapkan membuat masyarakat jera dan tidak akan melakukan perbuatan yang sama lagi. 
2. Rutin memberikan penyuluhan atau arahan untuk masyarakat dan muda $\cdot$ mudi setempat agar tidak melakukan kegiatan perjudian, karena dampaknya sangat negatif untuk masa depannya. Dan pihak kepolisian hams sering melakukan patroli keliling dan melakukan sidak ke tempat sering terjadinya tindak perjudian, untuk meminimalisir tindak perjudian yang sering terjadi di desa tersebut.

\section{DAFT AR BACAAN}

Burhan Bungin, 2005, Metodologi Penelitian Kuantitatif Komunikasi, Ekonomi, Dan Kebijakan Publik Ilmu-ilmu Sosial Lainya, Kencana, Jakarta.

G.W. Bawengan, 1977, Masalah Kejahatan Dengan Sebab dan Akibatnya,Jakarta, Pradnya Pararnitha

Ida Bagus Putu Purwita, 1989, Pengertian Tabuh Rah di Bali, proyek Penyuluhan Agama Hindu di Bali

Kartini Kartono, 1981, Pathologi Sosial, Jakarta, Rajawali Jilid I.

Mukti Fajar dan Yulianto Achmad, 2010, Dualisme Penelitian Hukum Empiris \& Normatif, Pustaka Pelajar. 